\title{
Market Response to Disclosure of Corporate Social Responsibility (CSR) During the Covid 19 Pandemic
}

\author{
Andi Faisal $^{1 *}$, Amiruddin Junus ${ }^{2}$, Darmawati Darmawati ${ }^{3}$ \\ ${ }^{1}$ Department of Islamic Banking, STAI DDI Sidrap, Indonesia \\ ${ }^{2}$ Department of Accounting, Hasanuddin University, Indonesia \\ ${ }^{3}$ Department of Accounting, Hasanuddin University, Indonesia \\ DOI - http://doi.org/10.37502/IJSMR.2021.4714
}

\begin{abstract}
This article aims to disclose the CSR on stock price and trading and examine the profitability as the reinforcement variable between CSR disclosure on stock prices and the trading volume during the covid-19 Pandemic. The object of the study was the LQ45 companies in the Indonesia stock exchange between 2019-2020. However, the study only involved 38 companies. We used the 2019 and 2020 data accessed from the official site of the Indonesia Stock Exchange (IDX) www.idx.com. The closing stock price and trading volume data were obtained from www.yahoofinance.com. Data were tested and analyzed using Partial Least Square (PLS) technique. The study found that the disclosure of CSR was positively but not significantly influential on the stock price. The disclosure of CSR is negatively but not significantly influential on the trading volume. The profitability does not strengthen the influence of CSR disclosure on stock price, and the profitability does not strengthen the negative influence of CSR disclosure on trading volume. The research findings suggest the company management continues to run CSR programs despite the unstable economic conditions due to the COVID-19 Pandemic.
\end{abstract}

Keywords: CSR disclosure, Stock price, Trading volume, Profitability, Covid 19.

\section{Introduction}

The stock market is a medium for a company to get additional capital by selling some of their ownership in the form of shares (Muklis:2016). Each company registered in the stock market will optimally try to increase their price per share to avoid losing a big amount of company ownership percentage (Kasmir:2007). One of the strategies employed by the company is to increase its stock price through information disclosure. According to the financial literature, information disclosed by the company will be immediately responded to by the market either positively or negatively (Ball \& Brown: 1968). However, in general, each positive disclosure will be positively responded to by markets.

Market response refers to the volatility of stock price and trade transaction volume. According to the theory of efficient market introduced by Fama (1970), stock price emerging in the market reflects all existing information. An increase in the stock price indicates the positive response of 
investors toward the information disclosed by the company. In other words, the more information disclosed by the company, the more investors will respond to them (Mutia: 2012).

Information disclosed by companies can be mandatory or voluntary (Healy \& Palepu: 2001). Mandatory information is obligated by the Capital Market Authority consisting of financial statements and nonfinancial statements (Organisation, Governance \& Corporate Responsibility) (Nuswandari:2009). The disclosure of a company's social responsibility has been regulated in the Indonesian constitution, which in this case the Laws No 40 of 2007 about Limited Liability Company, but items in Corporate Social Responsibility (CSR) that are disclosed have not been regulated.

Beside it is obliged to be disclosed by the company, the business sector is the growing awareness of CSR (Nurleni, at., al, 2018) CSR is also information that has an impact on market response. Some studies have investigated the influence of the disclosure of CSR on market response, including Tasnia et al (2020); Ender \& Breckmann (2019); Raverte (2016); Klrek \& Villaries (2014) and $\mathrm{Su}$, et al. (2014) \& Giovani (2013) who discovered the positive influence of CSR disclosure on the market response. Besides the market response, Dai, et al (2019) found that the disclosure of CSR reduces the risk of reduction on the stock price. However, a study by Fiori, et al (2015) found contradicted fact that in the Italian capital market, the CSR disclosure negatively affected the stock price.

Different findings were also resulted in studies conducted in the Indonesian capital market context. Some scientists found the positive influence of CSR disclosure on a market response like; Dazai, et al (2019); Chusaeri, et al (2019); Sulistiana (2017); Hamdani (2014); Vijaya (2012) \& Cheng \& Kristiawan (2011). In contrast, Astuti \& Nugrahanti (2015) found that the CSR disclosure does not affect the investor response in the stock market. Wulandari \& Wirajaya (2014); Restuti \& Nathaniel (2011) found that the CSR disclosure is not influential on the Earning Respond Coefficient (ERC), meaning that the disclosure of CSR does not convince the investor to make a decision.

Different research findings show that the effect of CSR disclosure on the market response varies according to contexts and situations. Especially in the global economic era, the Indonesian capital market grows very slowly due to the Covid 19 crisis. Mujib \& Candaningrat (2021) found that in the Indonesian capital markets, especially those under LQ45 industrial category, the announcement of the first case of Covid 19 negatively affected the stock market but was not significant. There was no difference in the abnormal return before and after the announcement of the first case of covid 19 in Indonesia.

This study follows up on research conducted by Mujib \& Candraningrat (2021) but treats CSR disclosure as an independent variable. In other words, this study aims to examine the impact of CSR disclosure on market response as the research object is companies included in the LQ45 category in the Indonesian stock market in the 2019 - 2020 reporting period. While in previous research, it was found that Covid 19 had a negative impact on the Indonesian stock market but not significant, this study investigates whether CSR disclosure is responded positively by investors during the current Covid 19 period.

This research contributes to the development of references regarding the stock market in Indonesia, especially during the Covid 19 pandemic. Previous research tended only to use the 
Abnormal Return variable to measure market response. Meanwhile, this research uses stock price volatility and Trading Volume Activity (TVA) to measure market response. These two variables are often used to measure market response by many scholars, such as; Sulistiana (2017); Astuti \& Nugrahanti (2015) \& Vijaya (2012). In addition, the researcher also involved the profitability variable as a reinforcing variable. Profitability is commonly used to measure the impact of financial information disclosure on the market response (Sambelay, et al, 2017; Dewi, 2015 \& Meyti, et al, 2011).

\section{Literature Review}

\subsection{Signalling in CSR disclosure}

Spancer (1973) defined signaling as a signal given by the owner (company) of information about the condition of the company that can benefit the information receiver (investor). While according to Birgham and Houston (2011), the theory of signal explains that perception of management is related to the company growth in the future. The signal is information that explains the company management's effort to actualize the wish of owners (shareholders). The information is an important signal which affects the investor decision.

The disclosure of the Company Social Responsibility (CSR) was initiated in the 1990s when Fmbrun and Shenley (1990) proposed a thesis that a company investing in social charities program will result in a positive impact on communities' response (Serbini: 2015). The CSR disclosure is regarded as a signal issued by a company for societies, especially the investors, about the company's performance at present and in the future. Lys et al. (2015) found that under the signaling hypothesis, all information (including the CSR disclosure) will be responded by the market while the investors observe the signal.

The CSR disclosure in the company annual report refers to Global Reporting Initiative (GRI) Standard. GRI is an independent international organization that has a role in assisting the company and government in understanding and informing the public about the impact of their business activities on the environment, society, and climate. The GRI disclosure has three focuses, namely: economic performance indicator consisting of 9 items, environment performance indicator consisting of 30 items, and social performance indicator consisting of 40 items including labor practices and decent work, human rights performance, society), and product responsibility performance (Vijaya: 2012).

\subsection{Stock price and Trading volume}

Share is a proof paper (certificate) of ownership of an entity. The shareowner has a right to get some profits and assets of the company (dividend). Stock price in the stock market is determined by the flexibility of demand and offer, which means that the more demand, the higher the stock price and vice versa (Harianto \& Hudomo. 1998 in Vijaya, 2012). According to Brigham (2010), shareowner property is determined by the stock price in the stock exchange. Thus, the company management should maximize the price from all shares distributed in the stock exchange.

A company can do CSR disclosure to provide information that investors can positively respond. Company with good performances on economy, social and environment will be positively responded by the investor through the increase of stock price. On the contrary, bad 
environmental and social responses will stimulate investors' pessimistic attitudes that can bring impact on the reduction of stock price (Rustiarini, 2010).

Trading volume is important for investors and prospective investors because it estimates the liquidity of the Issuer shares. The higher the transaction volume, the quicker and easier the share trading so that the shift of shares to cash is also getting faster. Basically, the speed of change in shares into cash funds is the determinant of stock liquidity (Wijayani \& Wijayanto, 2005). The trading volume of shares indicated total shares traded in a period of time (Tandelin, 2001).

\subsection{Profitability}

Profitability can be defined as the ability of a company to earn profit employing all resources it has, including sales, cash, capital, number of employees, and the number of branches (Harahap: 1998). In contrast, Munawir (2004) states that profitability indicates the company's ability to earn profit during a period of time.

Basically, each investor expects the maximum financial performance of a company (measured from the company's ability to get a profit). Information about profit is very important and most awaited by investors before deciding to buy or sell shares. If financial performance is good, it will also be responded well by investors and vice versa.

\section{Formulating the Hypothesis}

\subsection{Influence of CSR on stock price}

Many studies found that CSR influences stock price, although some other studies show different findings. Studies show the influence of CSR disclosure on stock price are like Tasnia et al. (2020); Ender \& Breckmann (2019); Raverte (2016); Klrek \& Villaries (2014), and Su, et al. (2014) \& Giovani (2013). Exclusively, Giovani (2013), in his study, found that the more CSR indicators disclosed (including economic, environmental, and social indicators), the higher the increase of stock price.

$\mathrm{H}_{1}$ : CSR disclosure positively affects the stock price

\subsection{Influence of CSR disclosure on Trading Volume}

Tandelin (2001) mentioned that stock trading volume illustrates the immediate market reaction and the number of shares traded in a certain period of time. Research by Vijaya (2012) shows that the disclosure of social responsibility has a positive effect on trading volume, although the effect is relatively small. Kahfi (2014) similarly found that CSR disclosure had no significant effect on trading volume. Meanwhile, Ayem \& Purwanto (2021) found the effect of CSR disclosure on stock trading volume but did not explain the significance

$\mathrm{H}_{2}$ : CSR disclosure positively affects the trading volume

\subsection{Influence of Profitability as the Moderate Variables on Stock Price}

Some findings show significant influence of profitability on stock price like Lumingkewas (2013); Suwandi, et al (2017); Sambaley, et al (2017); \& Wulandari and Badjra (2019). However, studies treating profitability as the variable strengthening the correlation between CSR 
disclosure and stock price are still limited (had not been found yet by the researchers). Based on the empirical examination on the influence of profitability on stock price, the researcher assumed that profitability could strengthen the influence of CSR disclosure on the stock price.

$\mathrm{H}_{3}$ : Profitability strengthens the influence of CSR disclosure on the stock price.

\subsection{Influence of Profitability as the Moderate Variables on Trading volume}

Several studies have found a positive and significant effect of profitability on trading volume. Some of them are by Reny, et al (2019) discovering that partially Return on Assets (ROA) and Tobin's Q had a positive and significant effect on stock trading volume, and Return on Assets (ROA) and Tobin's Q had a simultaneous positive and significant effect on the trading volume of shares. This means that the better the company's profitability performance, the more positive the market response.

$\mathrm{H}_{4}$ : Profitability strengthens the influence of CSR disclosure on trading volume.

\section{Research Methods}

\subsection{Population and Samples}

The population of the study is companies under LQ45 category in the Indonesian stock exchange. LQ45 is the term referring to 45 companies (issuers) that have fulfilled a number of requirements regulated by the stock authority. Some of them are issuers with the largest liquidity levels, companies with the highest market capitalization, and high financial conditions and growth prospects (Wikipedia).

The stock exchange authority updates LQ45 members annually. The LQ 45 investigated in this study are the ones in 2019 and 2020 lists. Due to the limited number of populations, the researchers did not select samples, and all members of LQ45 were involved in the research. However, because seven companies were not published the 2020 Annual Report on the Indonesian capital market website (www.idx.com), the study only involved 38 issuers.

\subsection{Data}

Data investigated in the study were CSR disclosure and company profitability published in the 2019-2020 Annual Report. Data were obtained from the Indonesian Capital Market site (www.idx.com). Data of stock price and trading volume were accessed from www.yahoofinance.com. The study employed the event study method and started the observation three days before the event and ended it three days after the event. The total observation window is seven market days to avoid the influence of other factors on the stock price. A longer observation window might let other events affect the investor reaction in the stock exchange.

The event date referred to when the issuer's Annual Report was announced (based on the announcement date on the Indonesian stock exchange) (www.idx.com). There is a difference between the date of the announcement in the company's official sites, capital market sites, and printed media (online). Therefore, the capital market site was chosen as the event date because it provides the official information of capital market activities. 


\subsection{Variable Measurement}

\subsubsection{CSR disclosure}

CSR disclosure was measured based on CSRDI (Corporate Social Responsibility Disclosure Index) proxy using GRI indicators. The study compared the number of disclosure performed by companies and the number of disclosure referring to GRI guideline indicators. The disclosure was conducted based on 91 items, including economic, environmental, labor practice, human rights, social, and product responsibility (GRI, 2006 in Waqiah, 2021). If an item is found in the annual report, it is labeled with a score 1 . If not, it is labeled with 0 . The number of index CSR (CSRI) is calculated by dividing the number of mentioned by issuer by the number of CSR items based on GRI (91 items).

$$
\operatorname{CSR} \mathrm{I}_{\mathrm{i}}=\frac{\sum \mathrm{x}_{\mathrm{yi}}}{\mathrm{n}_{\mathrm{i}}}
$$

Annotations:

CSRIj = Company's Corporate Social Responsibility Index

nj $\quad=$ Company's item disclosure score

$\mathrm{Xij} \quad=1=$ the item is disclosed, $0=$ the item is not disclosed

\subsubsection{Stock price}

In this study, the stock price refers to the company's daily closing stock price. The stock price of each company was observed in a 7-day observation window (3 days before the annual report announcement, in the days the yearly report was announced, and three days after the annual report announced). Because the closing stock price can be downloaded from www.yahoofinance.com we did not need the formula to calculate it.

\subsubsection{Trading volume}

Trading volume refers to the difference between the real volume and normal trading volume. The formula to calculate the trading volume is below:

Company traded shares

TVA $=\overline{\text { Company's outstanding share }}$

\subsubsection{Profitability}

A profitability ratio is a comparison that measures the company's ability to make profit from earnings like sales, assets, and capital using a particular calculation. This study used profitability as the strengthening variable of the influence of CSR on stock price and trading volume. The profitability was measured using the formula of Return on Investment (ROI) ratio as below:

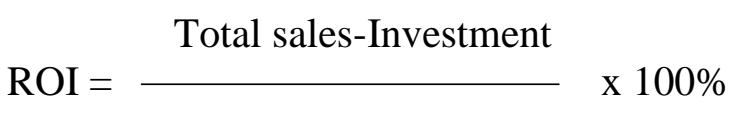




\section{Investment}

\subsection{Data Analysis Method}

Data analysis used in this study is the Partial Least Square (PLS) using the Smart PLS application. PLS stands for Partial Least Square, which is a measurement tool in the statistic method. PLS is a multivariate technique that can be used concurrently in various analyses like for response variable and explanatory variable (Alfa, et al:2017).

The conceptual framework mode of the study can be seen in the following chart:

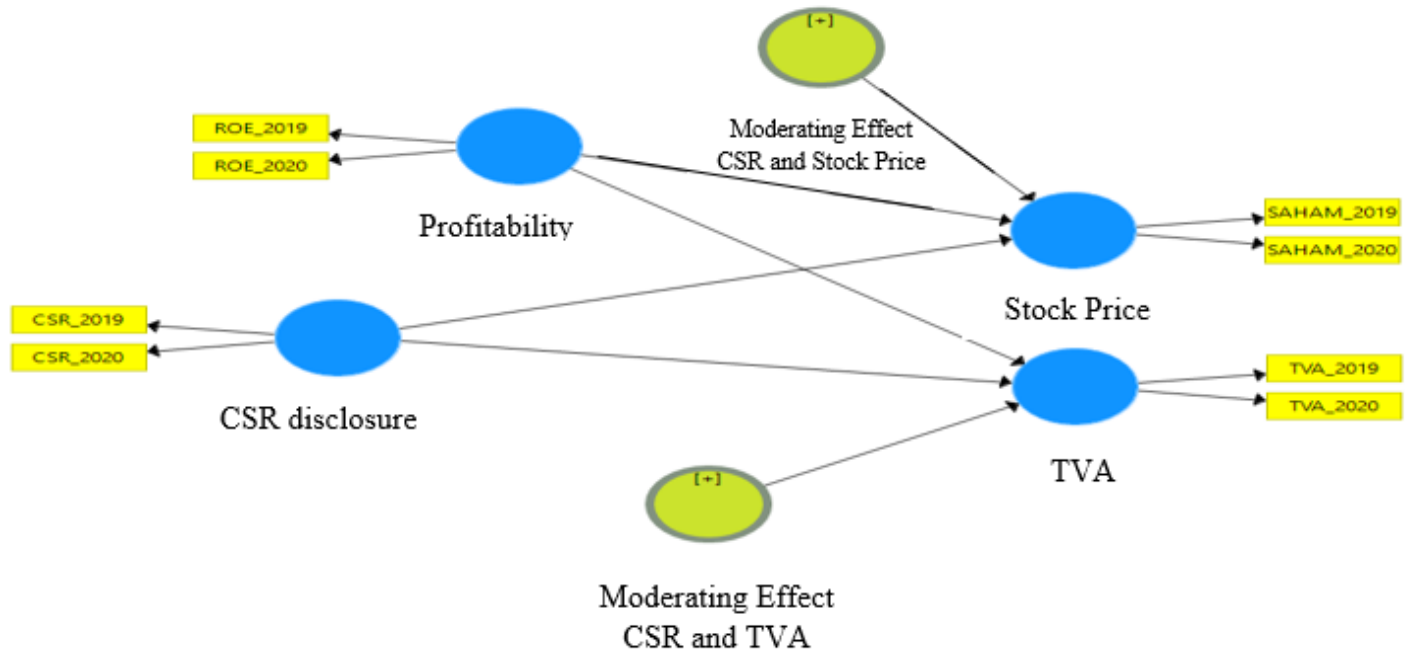

fig 1. Construct Model

\section{Research Findings}

\subsection{Loading Factors}

Loading factor is the estimated weight that compares factors and indicators. The loading factor standard is between 0 and 1 . The loading factor is categorized as significantly valid if it approaches 1. The estimated weight is obtained from squaring the loading factors (Hair et al., 2011). Conventionally, the score of the loading factor should be above 0.60 , indicating that it is higher than the error variance value. Thus, 0.60 is the minimum score equivalent to 0.36 (Hair et al., 2011). Therefore, scores below 0.60 are unable to be used because the error variance is more than $50 \%$. The measurement of loading factor is also referred to as the measurement of discriminant validity which is correlated with the principle stating that different construct measurers (manifest variable) should not be correlated. 
Table 1. Outer loading perceived ease of use

\begin{tabular}{|c|c|}
\hline Item & Outer loading \\
\hline CSR_2019 & 1.01 valid \\
\hline CSR_2020 & 0.9! valid \\
\hline CSR disclosure * Profitability & 0.6. valid \\
\hline CSR disclosure * Profitability & 0.6. valid \\
\hline ROE_2019 & 0.5. valid \\
\hline ROE_2020 & $0.9^{\prime}$ valid \\
\hline STOCK_2019 & $0.9^{\prime}$ valid \\
\hline STOCK_2020 & 0.9، valid \\
\hline TVA_2019 & 0.91 valid \\
\hline TVA_2020 & 0.8. valid \\
\hline
\end{tabular}

To test the convergent validity, we used the score of outer loading or loading factor. An indicator is categorized in the good category of the convergent validity if the outer loading value $>0,6$. Based on the analysis, each item in the variable of perceived use has an outer loading value $>0.6$. According to Chin in Imam Ghozali (2008), outer values between 0.5-0.6 have met the convergent validity requirement. Data above show that no items in the variable have outer loading value below 0.6 so that all indicators are regarded feasible or valid to be used in the study and can be analyzed further.

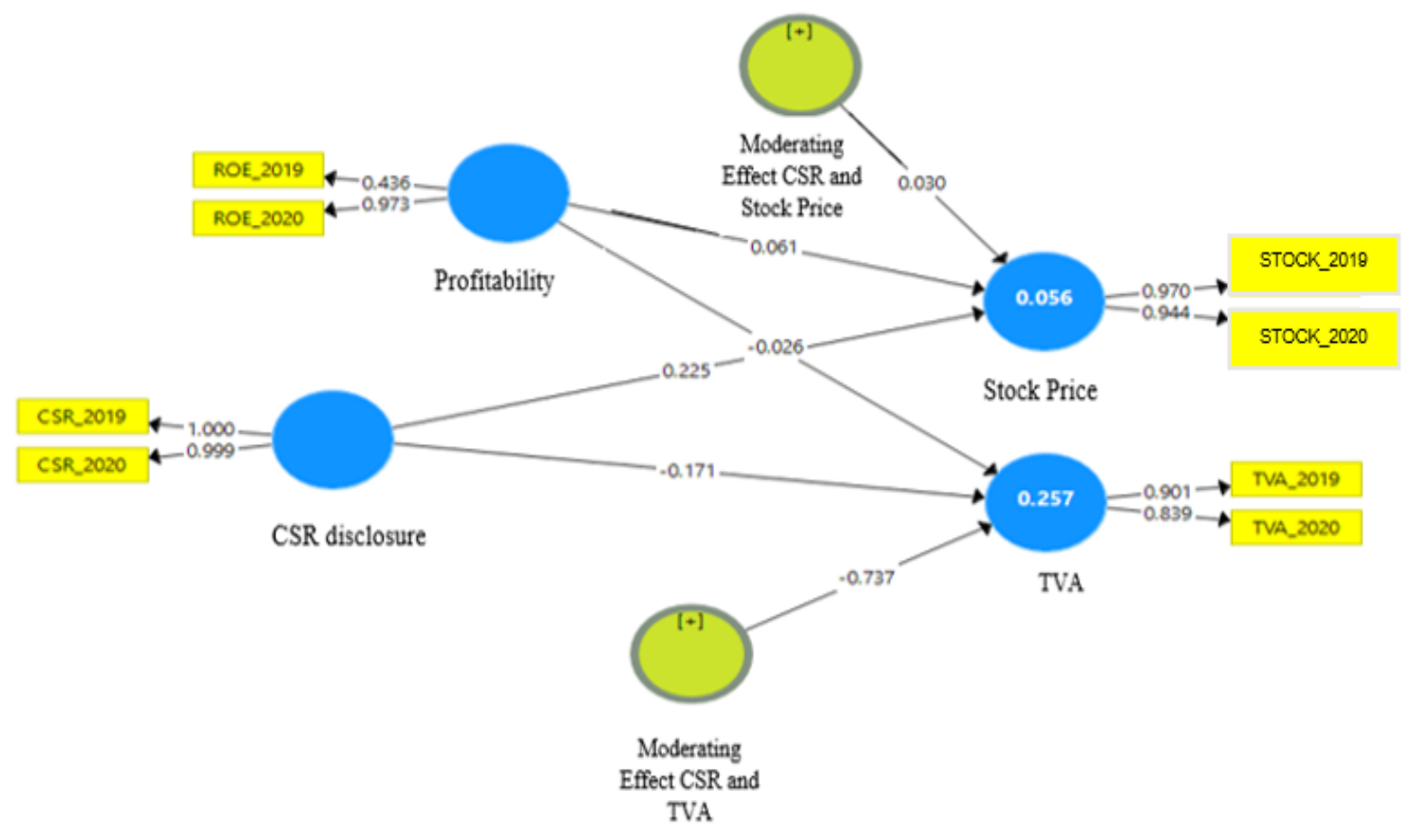

Fig 2. Inner \& Outer Model (R Square Test)

\subsection{Composite Reliability, Cronbach Alpha, Average Variance Extracted}


The composite Reliability test is the alternative of Cronbach Alpha test to measure the convergent validity of a reflective model. The value of composite reliability varies from zero to 1. For exploration study, the score of composite reliability should be at least 0.60 (Vinzi et al., 2010) or higher than 0,70. AVE test can be used to measure convergent and divergent validity. Results of the AVE test will reflect each latent factor in the reflective model. The reflective model is put in the good category when it is bigger than 0.50. however, according to Verhoet et al. (2002), an AVE score between 0.40-0.50 is still accepted as long as the composite reliability value $>0,7$. Cronbach Alpha test can describe the convergent validity. The score of Cronbach Alpha $>0,80$ is at good scale, $>0,70$ is at accepted scale, and >0,60 is at explorative scale which is estimated low.

Table 2. AVE Based on the analysis, the Cronbach's alpha, C.R., and AVE scores of the model have fulfilled the criteria.

\begin{tabular}{|c|c|c|c|c|}
\hline & $\begin{array}{l}\text { Cronbach's } \\
\text { Alpha }\end{array}$ & $\begin{array}{l}\text { rho } \\
\text { A }\end{array}$ & $\begin{array}{l}\text { Composite } \\
\text { Reliability }\end{array}$ & $\begin{array}{l}\text { Average Variance } \\
\text { Extracted (AVE) }\end{array}$ \\
\hline Stock price & 0.910 & $\begin{array}{c}0.9 \\
70\end{array}$ & 0.956 & 0.916 \\
\hline $\begin{array}{l}\text { Moderating Effect CSR and } \\
\text { stock price }\end{array}$ & 1.000 & $\begin{array}{l}1.0 \\
00\end{array}$ & 1.000 & 1.000 \\
\hline $\begin{array}{l}\text { Moderating Effect CSR and } \\
\text { trading volume }\end{array}$ & 1.000 & $\begin{array}{l}1.0 \\
00\end{array}$ & 1.000 & 1.000 \\
\hline CSR disclosure & 0.999 & $\begin{array}{l}1.0 \\
03\end{array}$ & 0.999 & 0.999 \\
\hline Profitability & 0.656 & $\begin{array}{c}0.8 \\
17\end{array}$ & 0.697 & 0.569 \\
\hline Trading volume & 0.684 & $\begin{array}{l}0.7 \\
08\end{array}$ & 0.862 & 0.758 \\
\hline
\end{tabular}

\subsection{Variance Inflation Factor (VIF)}

Collinearity illustrates the correlation between latent variables in the model, but the prediction is rather inaccurate and unstable. Collinearity test in construct formative is performed through the calculation of Variance Inflation Factor (VIF). Collinearity happens if the value of VIF $>10$, so that the variable should be discharged from the measurement model.

\begin{tabular}{lc}
\hline & VIF \\
\hline CSR_2019 & 2.939 \\
CSR_2020 & 2.939 \\
CSR disclosure * Profitability & 1.000 \\
CSR disclosure * Profitability & 1.000 \\
ROE_2019 & 1.049 \\
ROE_2020 & 1.049 \\
STOCK_2019 & 3.300 \\
STOCK_2020 & 3.300 \\
TVA_2019 & 1.369 \\
TVA_2020 & 1.369 \\
\hline
\end{tabular}


Variance Inflation Factor (VIF) is a method to detect multicollinearity. Based on the analysis of all constructs, there is no multicollinearity signal because the VIF score $<10$.

\subsection{Determination Test}

The Variant Analysis $\left(\mathrm{R}^{2}\right)$ or Determination Test aims to measure the influence of independent variables on the dependent variable. $\mathrm{R}^{2}$ is the determinant coefficient value which indicates the strengths of endogen variable prediction in the structural model.

\begin{tabular}{cc}
\hline & R Square \\
\hline Stock price & 0.056 \\
Trading volume & 0.257 \\
\hline
\end{tabular}

$\mathrm{R}$-Squares value is the result of a linear regression test referring to the rate of endogen variability that can be explained by the exogen variable. $\mathrm{R}^{2}$ score $=0.056$ shows the correlation between independent and dependent variables (stock price), which is at $5.6 \%$, and the correlation between independent and dependent variables at $25.7 \%$.

\subsection{Hypothesis Test}

Results of the test on the hypothesis can be seen in the table below:

\begin{tabular}{lccccc}
\hline & $\begin{array}{c}\text { Original } \\
\text { Sample } \\
(\mathrm{O})\end{array}$ & $\begin{array}{c}\text { Sample } \\
\text { Mean } \\
(\mathrm{M})\end{array}$ & $\begin{array}{c}\text { Standard } \\
\text { Deviation } \\
(\text { STDEV })\end{array}$ & $\begin{array}{c}\text { T Statistics } \\
(|\mathrm{O} / \mathrm{STDEV}| \\
)\end{array}$ & $\begin{array}{c}\text { P } \\
\text { Val } \\
\text { ues }\end{array}$ \\
\hline $\begin{array}{l}\text { Moderating Effect } \\
\text { Profitability) CSR -> Stock } \\
\text { price }\end{array}$ & 0.030 & 0.107 & 0.552 & 0.054 & $\begin{array}{c}0.95 \\
7\end{array}$ \\
\hline $\begin{array}{l}\text { Moderating Effect } \\
\text { Profitability) CSR -> }\end{array}$ & -0.737 & -0.817 & 0.767 & 0.961 & $\begin{array}{c}0.03 \\
7\end{array}$ \\
$\begin{array}{l}\text { Trading volume } \\
\begin{array}{l}\text { CSR disclosure -> Stock } \\
\text { price }\end{array}\end{array}$ & 0.225 & 0.205 & 0.166 & 1.359 & $\begin{array}{c}0.01 \\
7\end{array}$ \\
\hline $\begin{array}{l}\text { CSR disclosure -> Trading } \\
\text { volume }\end{array}$ & -0.171 & -0.123 & 0.319 & 0.537 & $\begin{array}{c}0.05 \\
9\end{array}$ \\
\hline $\begin{array}{l}\text { Profitability -> Stock price } \\
\text { Profitability -> Trading }\end{array}$ & 0.061 & 0.058 & 0.242 & 0.254 & $\begin{array}{c}0.80 \\
0\end{array}$ \\
volume & -0.026 & 0.030 & 0.359 & 0.074 & $\begin{array}{c}0.94 \\
1\end{array}$ \\
\hline
\end{tabular}

\section{Discussion}

Test on the first hypothesis $\left(\mathrm{H}_{1}\right)$ shows the positive but insignificant influence of CSR disclosure on the stock price at 0.255 , indicating that when the CSR disclosure increases, the stock price will incline by 0.255 . It means that when the company discloses the CSR, the stock price will also increase. The study is in line with the ones by Chusaeri, et al. (2019); Ender \& Brinckmen (2019); Sulistiana (2017); Klerk, et al. (2014) and Cheng \& Kristiawan (2011) finding that CSR disclosure has a positive impact on the stock price. However, the current study's findings do not confirm Fiori, et al. (2015) and Vijaya (2012), who stated that 
CSR disclosure does not influence the stock price. It indicated that in the Covid 19 pandemic, the investor still gave positive responses on issuers who conduct CSR activities.

Test on the second hypothesis $\left(\mathrm{H}_{2}\right)$ shows a negative correlation between CSR disclosure and trading volume but not significant which is at -0.171 , indicating that if the CSR disclosure increases, the trading volume reduces by 0.171 . The finding is contradicted with the proposed hypothesis and the studies conducted by Ayem \& Purwanto (2021) \&Vijaya (2012), which discovered the significant influence of CSR disclosure on trading volume. However, the current finding is in line with Astuti \& Nugrahanti (2015) and Kahfi (2014), which found that CSR disclosure has a negative influence on the trading volume. It is probably because the investors want the issuer to keep maintaining their cash flow in the Covid 19 pandemic. During this unstable condition, companies should be more careful in managing their cash flow to keep operate and earn profit.

The test on the third hypothesis $\left(\mathrm{H}_{3}\right)$ shows that profitability does not moderate the influence of CSR disclosure on the stock price. It means that the investors do not compare the CSR disclose and company financial performance before they decide to sell or buy the share. From the test on the first hypothesis showing that CSR disclosure positively affects the stock price, it is identified that CSR disclosure and profitability are not correlated. The finding indicates that investors will keep giving a positive response to companies that conduct CSR events without considering the percentage of return on investment (ROI).

The test on the fourth hypothesis $\left(\mathrm{H}_{4}\right)$ indicates that profitability moderation has an effect on the influence of CSR disclosure on trading volume at -0.737 . The role of profitability as a moderation variable improves the CSR influence. When it increases, there will be a reduction in trading volume by 0.737 .

\section{Conclusion}

The research findings show that CSR disclosure positively influences the stock price, on the contrary, it is negatively influential on the trading volume. Profitability does not strengthen the influence of CSR disclosure on stock price but strengthens the CSR disclosure on trading volume. Results of the test on the influence of CSR disclosure on Stock price are in line with the signaling theory. Investors regard CSR information as a positive signal on management performance. It is in line with some older studies like Chusaeri, et al. (2019); Ender \& Brinckmen (2019); Sulistiana (2017); Klerk, et al. (2014) and Cheng \& Kristiawan (2011). However, the results of the test on the influence of CSR disclosure on trading volume is contradicted with the theory. Yet, it supports some earlier findings like Astuti \& Nugrahanti (2015) and Kahfi (2014). The profitability does not strengthen the influence of CSE disclosure of stock price but strengthens the negative influence of CSR disclosure on trading volume.

The findings have positive implications on the empirical literature about CSR disclosure and the stock market, especially during the unstable economic condition due to the covid 19 pandemic. The findings are also important information for company management to keep conducting CSR programs although the economy is still unstable. 
The study has some limitations like the lack of financial report publication in 2020 in the market stock site www.idx.com. And the profitability measurement only used Return on Investment (ROI), ratio. Thus, the next researchers should use more profitability measurement.

\section{References}

1) Astuti, Christina dan Nugrahanti, Y.W. 2015. Pengaruh Pengungkapan Corporate Social Responsibility Terhadap Reaksi Pasar. Dinamika Akuntansi, Keuangan dan Perbankan. Vol. 4, No. 2.

2) Ayem. Sri dan Purwanto, N.U. Pengaruh Informasi Arus Kas, Leverage dan Pengungkapan Corporate Social Responsibility (CSR) terhadap Trading volume Saham Perusahaan Perbankan di Bursa Efek Indonesia. Forum Ekonomi, 23 (3).

3) Chusaeri, Na'am. et al.. 2019. Pengaruh Good Corporate Governance dan Pengungkapan Corporate Social Responsibility terhadap Stock price Perusahaan yang Terdaftar di Bursa Efek Indonesia (BEI) Periode 2014-2016. E-Jra Vol. 08 No. 04.

4) Dewi, L.K. 2015. Pengaruh Profitabilitas, Leverage dan Likuiditas terhadap Stock price pada Perusahaan Industri Makanan dan Minuman di Bursa Efek Indonesia. E-Jurnal Katalogis, Vol. 3 No. 8.

5) Ender, Manuela and Brinckmann, Finn. 2019. Impact of Csr-Relevant News on Stock Prices of Companies Listed tn The Austrian Traded Index (Atx). Int. J. Financial Stud. 7, 36.

6) Fiori, Giovani. et.al. 2015. Corporate Social Responsibility and Stock Prices: A Study on The Italian Market. Corporate Ownership \& Control / Volume 12, Issue 2.

7) Goh, T.S. et.al. 2021. Determinants and Prediction of The Stock Market During Covid19: Evidence from Indonesia. Journal of Asian Finance, Economics and Business Vol. 8 No. 1.

8) Hamdani, Mailani. 2014. Hubungan Pengungkapan Corporate Sosial Responsibility (CSR) terhadap Kinerja Keuangan dan Stock price pada Perusahaan LQ45. Jurnal Organisasi dan Manajemen, Vol. 10 No. 1.

9) Healey, P.M and Palepu, K.G. 2001. Information Asymmetry, Corporate Disclosure, and The Capital Markets: A Review of The Empirical Disclosure Literature. Journal of Accounting and Economics 31

10) Herwany, Aldrin. et.al. 2021. The Influence of The Covid-19 Pandemic on Stock Market Returns In Indonesia Stock Exchange. Journal of Asian Finance, Economics and Business Vol 8 No 3.

11) He, Pingling, et al. 2020. Covid-19's Impact on Stock Prices Across Different SectorsAn Event Study Based on The Chinese Stock Market. Emerging Markets Finance and Trade 2020, Vol. 56, No. 10.

12) Iskandar, dkk. 2013. Pengaruh Rasio Profitabilitas terhadap Trading volume Saham. Jurnal Manajemen Vionist Volume 2 Nomor 1.

13) Klerk, et.al. 2014. The Influence of Corporate Social Responsibility Disclosure on Share Price. Pacific Accounting Review, Vol. 27 Issue 2.

14) Liu. L, et.al. 2020. Impact of The Covid-19 Pandemic on The Crude Oil and Stock Markets in The Us: A Time-Varying Analysis. Energy Research Letters. Vol 1. Issue 1. 
15) Lumingkewas, Cherry. Pengaruh Profitabilitas Terhadap Stock price. Journal of Business and Economics. Vol. 12, No. 2.

16) Mujib, Barrul and Candaningrat, I.R. Capital Market Reaction to Covid-19 Pandemic on LQ45 Shares At Indonesia Stock Exchange (IDX). American Journal of Humanities and Social Sciences Research (AJHSSR). Volume-5, Issue-3.

17) Mutia, Evi. 2012. Pengaruh Informasi Laba dan Arus Kas terhadap Stock price. Jurnal Akuntansi, Vol. 1, No. 1.

18) Nurleni Nurleni, Agus Bandang, Darmawati -, Amir Amiruddin, "The effect of managerial and institutional ownership on corporate social responsibility disclosure", International Journal of Law and Management, https://doi.org/10.1108/IJLMA-032017-0078

19) Reny, A.R, Et al.. 2019. Pengaruh Return on Asset dan Tobin's Q terhadap Trading volume Saham pada Perusahaan Perbankan yang Listing di Bursa Efek Indonesia Periode Tahun 2013-2017. Indonesian Journal of Business and Management. 1 (2).

20) Sambelay, J.J 2017. Analysis Effect of Profitability on Stock Price Listed In LQ45 in Period 2012-2016. Jurnal Emba Vol. 5 No. 2.

21) Sulistiana, Indra. 2017. Pengaruh Pengungkapan Corporate Sosial Responsibility dan Rasio Profitabiitas terhadap Stock price pada Perusahaan Manufaktur yang Terdaftar di Bursa Efek Indonesia. Jurnal Akuntansi Vol. 4, No. 2.

22) Suwandani, et.al. 2017. Pengaruh Profitabilitas terhadap Stock price Perusahaan Manufaktur Sektor Makanan dan Minuman di BEI Tahun 2014-2015. Jurnal Akuntansi dan Pajak. Vol. 18, No 1.

23) Tasnia, et.al. 2020. The Impact of Corporate Social Responsibility on Stick Price Volatility of The Us Banks: A Moderating Role Of Tax. Journal Of Financial Reporting and Accounting. Vol. 18, 1ssue 3.

24) Vijaya, D.P. 2012. Pengaruh Pengungkapan Tanggung Jawab Sosial Perusahaan terhadap Aktifitas Trading volume. Jurnal Ilmiah Akuntansi dan Humaniora. Vol 3.

25) Wulandari dan Wirajaya. 2014. Pengaruh Pengungkapan Corporate Sosial Responsibility terhadap Earnings Response Coefficient. E-Jurnal Akuntansi Universitas Udayana. Vol. 6, No. 3.

26) Wulandari, A.I dan Badjra, I.B. 2019. Pengaruh Profitabilitas terhadap Stock price pada Perusahaan LQ-45 Di Bursa Efek Indonesia (BEI). E-Jurnal Manajemen, Vol. 8, No. 9. 